\title{
Endangered, Neglected, Indigenous Resilient Crops: A Potential against Climate Change Impact for Sustainable Crop Productivity and Food Security
}

\author{
B. E. SAMBO \\ Department of Crop Scienc, Federal University Dutse, P.M.B.7156, Jigawa State - Nigeria.
}

\begin{abstract}
Globally, agriculture is critical for food security and source of livelihood for approximately 500 million households. The small hold farmers provide food for about $70 \%$ of the world population today. The impact that climate change is predicted to have on farming is, thus, a major threat to world food security. It is against this background that this work takes a retrospective swipe to highlight the imperative need to exploit the adaptive resilient qualities offered by the rich bio-diverse indigenous crops of the Nigerian cum African agricultural landscape towards meeting the challenges posed by climate change, and the consequent loss of biodiversity and declining crop productivity, amidst the global food crisis. It is reported that most endandered, neglected, indigenous/ "native," African crops such as Acha (Digitaria exilis), Benniseed (Sesanum indicum, L.), Ginger (Zingiber officinale Rosc.), indigenous Millet (Pennisetum typhoideum), Guinea corn (Sorghum bicolor) and the likes, have low water demands; as such tolerate drought stress. They grow productively on soils inherently low in fertility and their nutrients demand could be met locally through low cost organic sources. These crops are well able to adapt and cope with stress factors in the region; with increased temperature and reduced rainfall, and thus, offer a potential in the fight against climate change. The combined threat of disease, climate change and loss of biodiversity means that food shortages are inevitable and this situation could escalate as human population increases globally. The fear is that many useful indigenous/wild species could disappear - leaving rural communities less resilient and vulnerable to changing weather patterns. The adaptation of agriculture to climate change would depend on the conservation and introduction of crop wild relatives from the rich "native"/indigenous bio-diverse stocks. This could hold the key for developing climateproof crops.
\end{abstract}

Keywords: Agriculture, climate change, resilient, bio-diversity, sustainability, food security

\section{Introduction}

Globally, agriculture is critical for food and livelihood security, for approximately 500 million smallholder households, totaling 1.5 billion people, living on smallholdings of two hectares of land or less; accounting for $85 \%$ of the world's farms [1]. These small scale food producers provide food for about $70 \%$ of the population today. The impact that climate change is predicted to have on farming is thus a major threat to world food security. For instance, it is predicted that over half a billion people in the tropics - 526 million people - could be at risk of hunger because of climate change by 2050, according to recent estimates by the Program on Climate Change, Agriculture and Food Security (CCAFS) [2]. Indeed, climate change portends a major threat to the livelihoods and food security of billions of the planet's poor and vulnerable, as it seriously jeopardizes to agricultural production [3].

But climate change is not the only threat to food production. Water scarcity, high energy prices, desertification and other forms of land degradation - such as saline soils - and crop land losses due to bio-fuels, timber, expanding cities and other factors [4]; which will invariably make it harder for humanity to feed itself [5].

Although agriculture, in the dominant conventional and industrial models as it is practiced today, is also a major contributor to greenhouse gas (GHG) emissions (3Ching and Stabinsky, 2011). And at the same time as it poses a huge climate threat, industrial agricultural systems are highly vulnerable to climate change. The industrial model and the crop varieties designed to work well within it depend on energy - and water intensive irrigation as well as other fossil fuel - intensive inputs such as mechanized harvesting, fertilizers and pesticides. The model, according to [6], is highly vulnerable to reductions in the availability of fuel and water, and in the long-term is economically unsound. Consequently they posited that nothing less than a system change is needed in the face of the climate change threat.

Indeed, according to the UK's Hadley Centre for Climate Change, temperature increases in parts of Africa could be double the global average increase. Given Africa's heavy dependence on agriculture, its high proportion of low-input, rain fed farming (95\%) and existing stresses such as land degradation and population pressure, the impact there is likely to be the greatest. An increase of 5 to $8 \%$ of arid and semi-arid land in Africa 
is projected under a range of climate-change scenarios. Climate change will affect livestock by changing the yield and nutritional quality of fodder, increasing disease and disease-spreading pests, reducing water availability, and making it difficult to survive in extreme environments - without a doubt, changes in weather patterns are inevitable and these will have significant impacts on agriculture, forestry and fisheries, as well as on infrastructures and lifestyles [7].

The more measured forecasts envisage a future with entirely new climatic zones, which will put significant strains on agriculture, affecting how producers earn a living [7]. Therefore, climate change is considered an individuals or social groupings potential weakness to some forms of natural hazard and is determined primarily by the existent state such as the capacity to respond to stresses brought by external shocks compared to the less healthy individuals or degraded ecosystems.

Persistent drought, incessant rain, flash floods, hurricanes, forest fires - climate change poses countless challenges for farmers, pastoralists and others who depend on natural resources for their living. Poor rural communities and countries bear the brunt of such climate-related disasters. Thus, the initiative to respond to change offers an entry point to sustainable processes of climate-change adaptation (CCA) [8].

A focus on climate challenge to the ecosystem and livelihood is therefore needed, particularly as the adaptation needs of developing countries is paramount. Therefore there is a dire need by all stake-holders in the agricultural sector to systematically redirect agricultural knowledge, science and technology towards sustainable, biodiversity-based ecological agriculture and the underlying agro-ecological sciences [9]. This is because it is postulated that the ecological model of agricultural production, which is based on principles that prioritize farmers and traditional knowledge, is climate resilient as well as productive. Many answers will lie on the farmer's knowledge to grow a diversity of crops to create the resilience needed to face increased unpredictability in weather patterns [3]. Certainly, climate change will require a series of adaptations approaches, such as shifts in many elements of agricultural production systems; to changes in crop varieties grown; to drastic decisions to abandon cropping completely [10].

It is against this backdrop that this work is aimed to X-ray and highlight the need to look inwards and exploit the climatic adaptive qualities and resilience of some of the many neglected, endangered, indigenous crops that have served and sustained Africa and other continents, for thousands of years as: Acha (Digitaria exilis), Benniseed (Sesanum indicum, L.), Ginger (Zingiber officinale Rosc.), indigenous Millet (Pennisetum typhoideum), Guinea corn (Sorghum bicolor); African nightshade; vegetable amaranth; indigenous bambara nuts; pigeon pea amongst others (Plates 1 - 10).

\section{Discussion}

\subsection{The Adaptive Resilience of Indigenous, Neglected and Endangered Crops Could Enhance Food Production}

\subsubsection{Growing climate-resilient crop varieties}

Of course, climate change will have impacts on agriculture and the extent of these impacts will depend, to a large part, on the ability of producers to respond and adapt to future climate conditions. Therefore, this requires immediate efforts to build resilience and adaptive capacity in the face of existing vulnerability and high levels of uncertainty [11].

Because of the enormous challenge posed by climate change, there is the need to proffer alternative mechanism or ways for tackling global warming. In this regard, it is suggested that a blend of global and more localized strategies can do much to help producers weather the effects of climate change. This includes conservation agriculture, organic agriculture, carbon sequestration and the capacity to withstand weather stresses, change in planting time, and the breeding of a number of climate-resilient crop varieties amongst others $[7,12]$. Some of these climate resilient crop varieties have already reached farmers fields, while more are being developed. In fact, in Mali, farmers in the relatively cool, wet region of Sikasso, who grow maize and cotton, could benefit by turning to sorghum and millet, crops currently grown in Segou, in the hotter, drier north. Similarly in Western Kenya, farmers have quintupled their yields in a year, using a drought-resistant variety of maize. Another study in the Gambia showed that millet crop yields can be increased even in a climateconstrained world with harvests improved by $13 \%$ if new varieties are used [7].

In effect, climate change is forcing scientists to rethink priorities and focus on stress tolerant rather than high yielding varieties. In this regard, Researchers at the International Crops Research Institute for the SemiArid Tropics (ICRISAT) are working at developing pearl millet, sorghum, chickpea, pigeon pea and groundnut to grow in a warmer world. Presently, varieties tolerant to heat, high soil temperatures, low and variable rainfall and diseases amongst others have been produced. In spite of despite reservations, a growing body of experts believe that genetic modifications holds the key to developing climate-resilient crops; as trails on droughttolerant maize developed by Monsanto are on-going in South Africa, have shown [7]. 


\subsubsection{Endangered, Indigenous/ "Native" Crops Have Potentially Sustained Africa}

Allan Savory (founder of Zimbabwe-based Africa Center for Holistic Management), had argued that money - and even agricultural techniques based on Western agriculture, may not be the answer to global food insecurity; as these approaches typically are said to involve the use of synthetic fertilizers, stronger pesticides, and genetically modified seeds to increase yields - all tactics that view the soil as a "problem" to be solved rather than as a resource that offers its own unique opportunities, and requires its own special treatment. It has been highlighted that the real problem with using Western agricultural methods - as in Kenya for example - is the loss of superb diversity that once made indigenous plants a reliable and nutritious native food source. According to her "of the approximately 200 indigenous species of plants that were used by Kenyans as vegetables in the past, most were either collected in the wild, semi-cultivated, or cultivated; and now many are either unknown or extinct." In view of this, they proffer a long-term solution that uses the tools at hand to effect a lasting revolution in regional agriculture - called "indigenous food" revolution; with the re-introduction of such varieties as African nightshade and vegetable amaranth to regional farmers. These farmers (groups) are trained in all aspects of growing indigenous crops, from seed production to processing, using organic methods; and they in turn pass on their knowledge of indigenous food growing to others in their communities. She avers that the hot, arid lowlands being used for indigenous bambara nuts and pigeon pea yields relatively better in the low fertility soils and with low rainfall. And this allows for a diversified, sustainable production model that insures nutritional security and prosperity; and one cannot talk on the issue of nutrition security, poverty, and health in Kenya, and many other regions today, without relying on African indigenous crops [13].

Without a doubt, the rich bio-diversity presented by the African agricultural landscape offers an abundance (of germplasm) of such naturally occurring drought, stress tolerant and resilient crops. And in the arid or semi-arid Savannahs of (northern) Nigeria exists one such potential crop locally called acha, in the native/local Hausa language and Tzwan amongst the Bajju speaking peoples of Southern Kaduna, Nigeria. Acha is reported among the first crops to be domesticated in Africa [14]; and West Africans generally have cultivated it for thousands of years - where it is thought to probably be the oldest African cereal and forms an integral part of the local diet and culture; even though, few other people have ever heard of it [15]. But, despite its ancient heritage and widespread importance, the knowledge of acha remains scanty, even within West Africa itself. In Nigeria, it is grown mostly in the up-lands of Plateau state where temperatures are cooler [16]; and in the Kwoi (Jaba) region of Southern Kaduna [17]; where the crop is most adapted to the vagaries of climate. There are no improved varieties of acha; and yields are generally very low [18]. It is planted on light (sandy to stony) soils and fertilization is mainly on rich organic soils. The acha grains are used in several ways - as a recommended food for diabetic patients, as porridge and couscous and/ or mixed with other flours to make break. It is also brewed for beer; and the grain, straw and chaff are used for animal fodder and the straw is sometimes chopped and mixed with clay to make bricks $[19,20,21,22,23]$. In this regard, indigenous crops as acha, that have remained important in the rural economy, offer great potentials for increasing Nigeria's/Africa's food security. The fact that the scientific community and producers alike, pay no attention to of such bio-diverse indigenous crops, is probably said to be the price modern Africa is paying for neglecting most of its over 2000 "native" crops that sustained it for thousands of years; in the face of the global climatic (warming) changes [24, 25].

The reported inherent adaptive resilience and tolerance of indigenous African crops to poor and marginal soils $[21,15]$; and low water demands; makes them tolerant of soil stress and hence surviving strong droughts [26, 27]. This implies that these crop plants are well able to cope with stress in regions with increased or reduced temperatures and reduced rainfall. This adaptation to the vagaries of the climate could well mean that over time, the crop had or will inherently evolved structures and/ or organs, adjustably in response to increasing temperatures and decreasing rainfall regimes in certain areas; in order to conserve scarce available water and help cope with rising temperatures. Equally important in reducing vulnerability is the ability of these crop plants to grow productively on soils inherently low in fertility and without chemical inputs in its production; while its fertilizer requirements are easily locally met through organic fertilization such as the use of animal manure [28]. Since many indigenous crops are basically grown on rich organic soils, the benefits of organic farming could be underscored to include amongst others: its potential for reducing emissions; as it requires less fossil fuel per hectare and kilogram of produce due to its avoidance of synthetic fertilizers: it effectively reduces soil erosion which is an important source of carbon dioxide losses: it enhances soil fertility which leads to a stabilization of soil organic matter and, in many cases, to a sequestration of carbon dioxide into the soil; this in turn increases the water retention capacity, allowing for better adaptation of organic agriculture under unpredictable climate conditions with higher temperatures and uncertain precipitation levels: consequently, organic production methods emphasizing soil carbon retention are most likely to withstand the climatic challenges particularly in those countries most vulnerable to increase climate change: and because of the application of traditional skills and farmers' knowledge, organic systems are said to maintain a high degree of biodiversity [29, 30, 31]. 


\section{Adaptive, Resilient/ "Native" Crop Seeds Could Help Preserve the World's Food Heritage}

It is on record that, in Mexico, Guadalupe Ortiz founded Canasta de Semillas (Basket of Seeds) due to "the need to reclaim "native/indigenous" seeds in order to ensure food security and face the challenges of climate change and the emergence of new pests." These seeds are said to have resisted all the changes that have taken place; and are distributed to the community banks and from where nearly all are loaned out to farmers, who will replace it when they harvest their crops. Indeed, a national campaign was launched with the slogan "For the right to life, save our native seeds! Defend Mexico's food heritage!" The campaign aimed to highlight the importance of the sustainable agriculture carried out by farmers and indigenous people for production of sufficient, nutritional food, as well as for overcoming the food crisis, conserving and improving natural resources and developing resilience to climate change. The national campaign includes creating seed banks managed by local communities, to improve knowledge about, protection of and propagation of the seeds, and organizing fairs where "campesinos" can exchange seeds and swap experiences about their preservation [32].

Undeniably, there is a general agreement that the adaptation of agriculture to climate will depend upon the conservation and introduction of crop wild relatives. In this respect, it is advocated that there in situ conservation and community breeding for higher yields is desirable and must be supported [33]. This is against the backdrop that, today, the industrial food chain is reported to concentrate on 150 species with almost all research going into 12 species. While the peasant food web breeds and nurtures 7,000 food crops, offering enormous potential to respond to climate change. Indeed, over the last half-century, industrial breeders are reported to have produced about 80,000 plant varieties (including 7,000 from international research centers). Almost $60 \%$ of private commercial breeding has been ornamental. But over the same time, peasants have contributed close to 2.1 million food and feed varieties [34]. All this underscores the fact that policies must surrender breeding directions to peasant organization and duplicate gene banks accessions for peasant breeding and inter farm exchange.

\section{Governments Have a Duty amidst a Food Crisis Ridden World}

Action Aid's research had shown that 1.6 billion people - nearly a quarter of the world's population live in countries that are highly vulnerable to climate-related food crisis. They have very high underlying levels of chronic hunger and child malnutrition, coupled with rapid rates of land degradation that will make food production increasingly difficult as global warming intensifies. Increased vulnerability to drought and floods, erratic and extreme weather conditions across Asia, Africa and Latin America, is reducing the ability of communities to feed [35].

Already, scientists have estimated that global production of key stable, such as wheat and corn, has fallen by $3.8 \%$ and $5.5 \%$ respectively over the last three decades, as result of climate change. Crop yields from rain-fed agriculture in some southern African countries could fall by up to $50 \%$ by 2020 because of climate change, and yields in central and south Asia could fall by $30 \%$ by 2050 [2]. Consequently, in Kenya, noted with a soaring food crisis, and maize harvests predicted to be $16 \%$ below former years as a result of changing Kenyan weather patterns, the only grains that could adequately replace maize would be indigenous millets and sorghum, which are drought tolerant [13].

In this regard, African governments must step up and invest in making agriculture robust and resilient to enable food to be grown in a climate-stressed environment. To this end, Malawi and Rwanda - two of the poorest countries in the world but nonetheless are reported to be inspiring in investing in agriculture; planning well for climate change, and beginning to expand social welfare systems to cushion poor people from hunger shocks. Also, they must devote at least $10 \%$ of their annual budgets to agriculture and ensure that the majority of this support goes towards staple crops on which poor communities depend. Lastly, they must expand and support sustainable, agro-techniques that enhance the use of local seed varieties amongst other measures such as reduced use of chemicals which have been proven to increase climate resilience and combat land degradation [35].

\section{Conclusion}

The concurrent loss of locally-adapted and locally-available crops and plant varieties is of mounting concern, because it leaves rural communities less resilient and adaptive to changing weather patterns and conditions (climate change) in the face of scaring abject poverty, degenerating living conditions of peoples amidst the global food crisis. Indeed, climate change poses a threat to biodiversity (significant losses of genetic resources), and the fear is that many useful wild species could disappear. Notwithstanding, drought resistant, low input requirement crops, from Africa's indigenous, rich bio-diverse stocks, could offer scientists a rich source of genetic material for modifications; which could yet hold the potential key to developing climateresilient /drought-tolerant crops. The solution, suggests harmony with nature rather than an attempt to control it - which may be the only way forward in a warming/ changing climate world. 


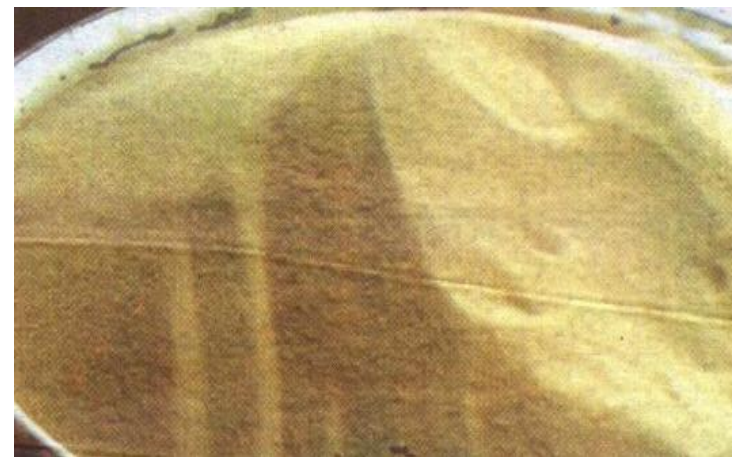

Plate 1:Acha grains on sale in the open market plants

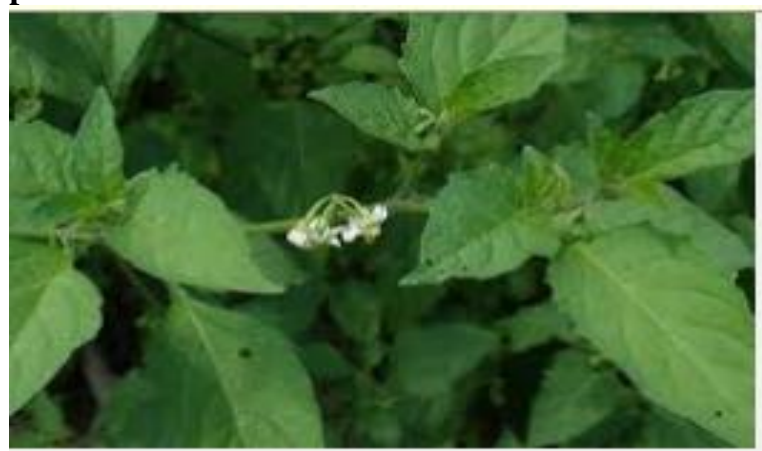

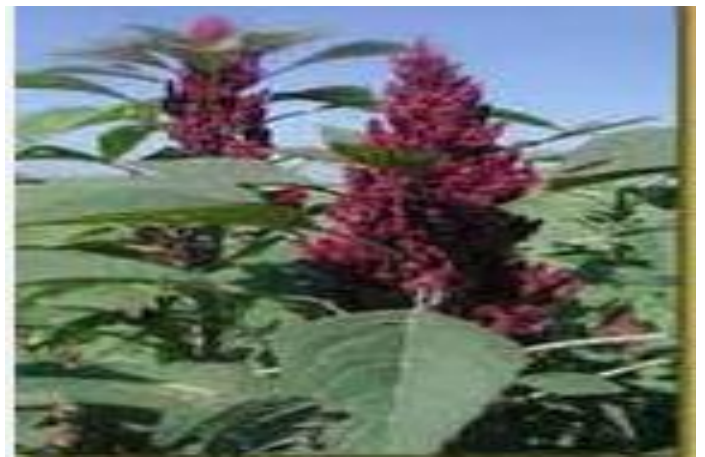

Plate 2: Growing amaranth crop

Plate 3: Left and Right. Growing African night shade crop plants

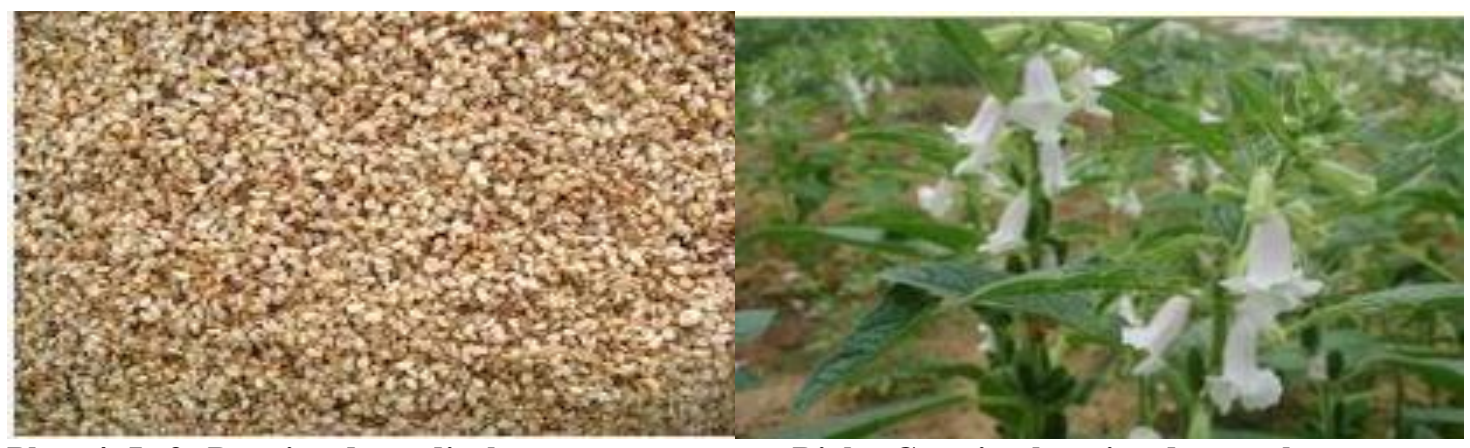

Plate 4: Left. Benniseeds on display

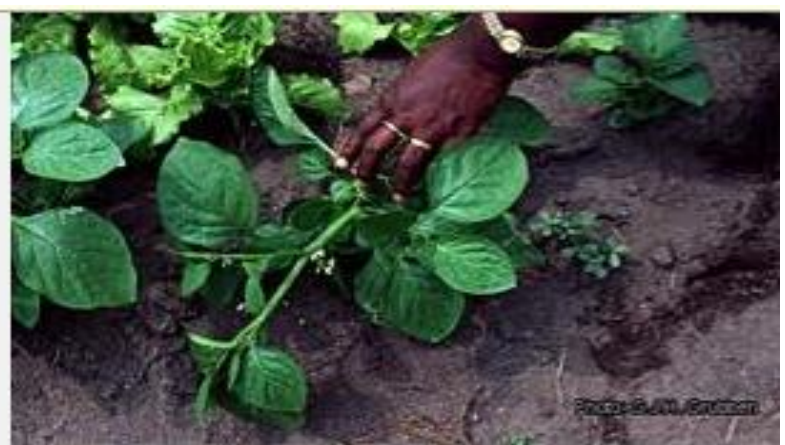

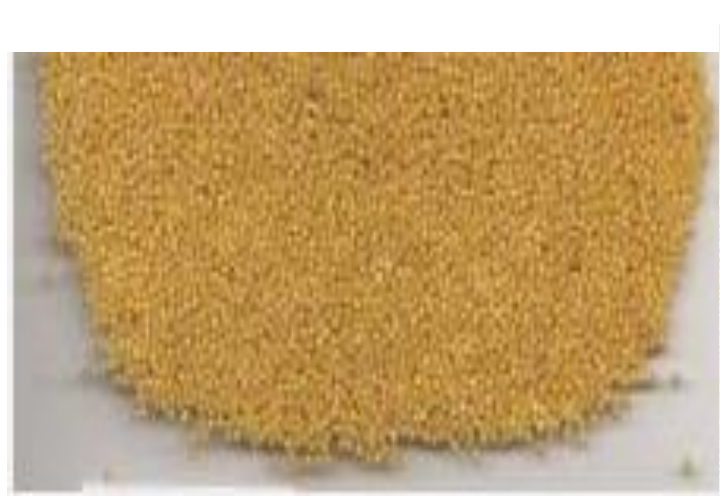

Plate 5: Left. Millet grains on display heads
Right. Growing benniseed crop plants

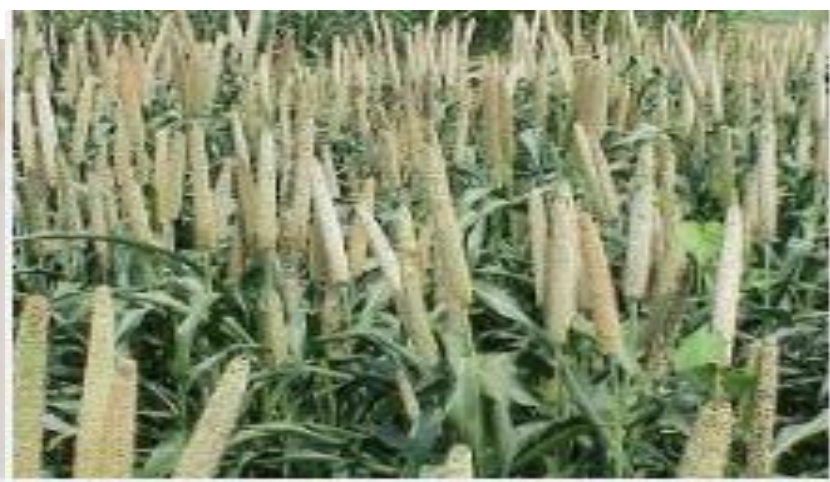

Right. A growing millet crop on the field with 


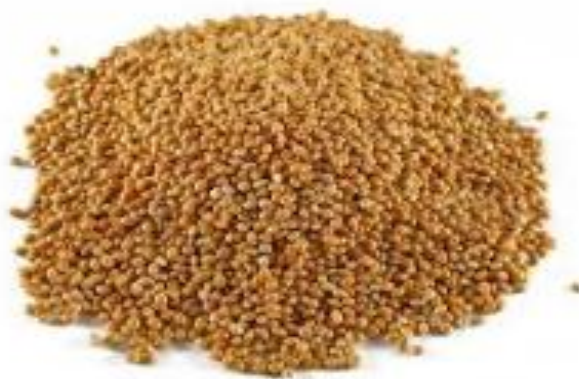

Plate 6: Left: Sorghum grains on display grains

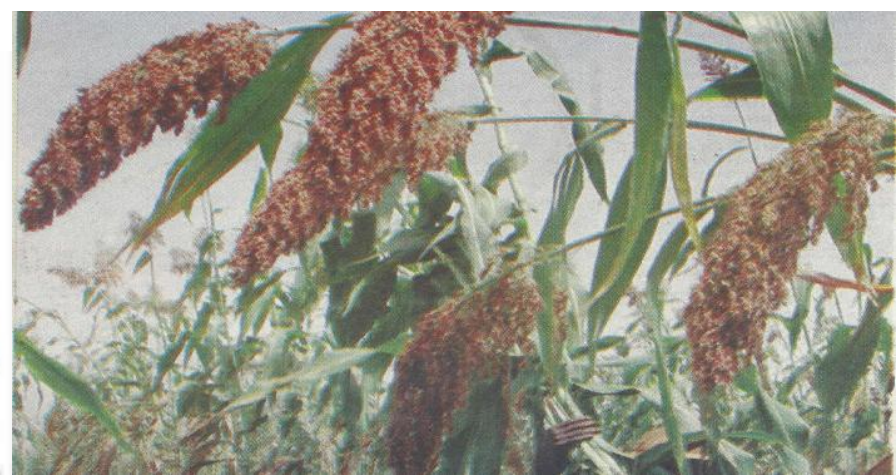

Right. A growing Sorghum crop with heads bearing

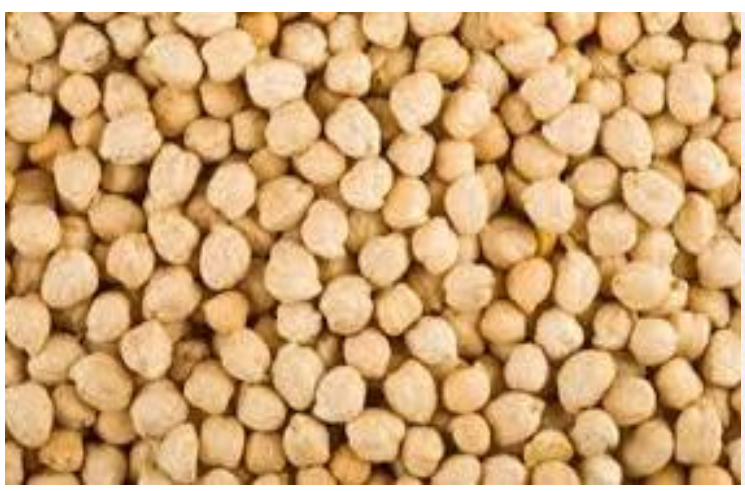

Plate 7: Left. Chick pea seeds

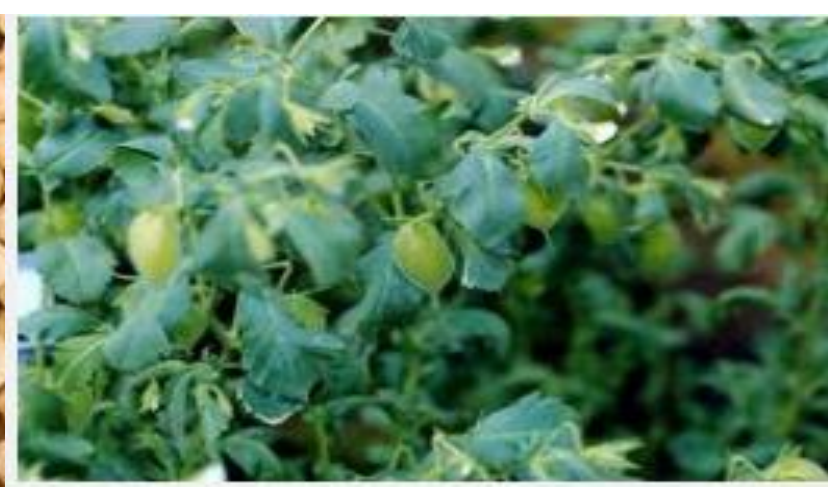

Right. A growing chick pea crop in the field

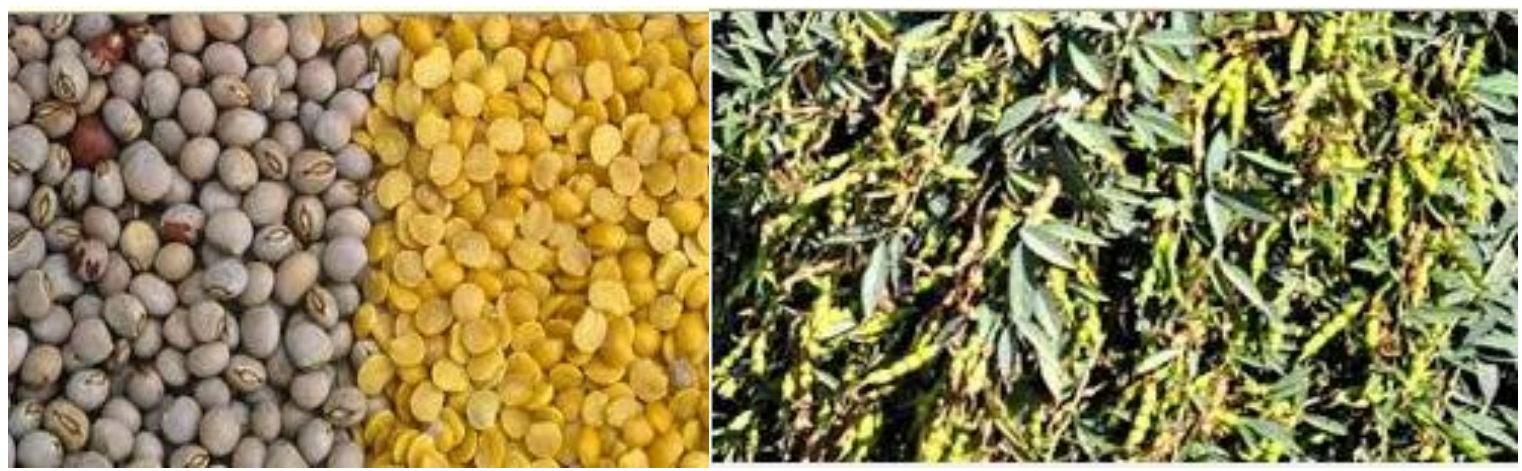

Plate 8: Left. Pigeon pea seeds

Right. A growing pigeon pea crop

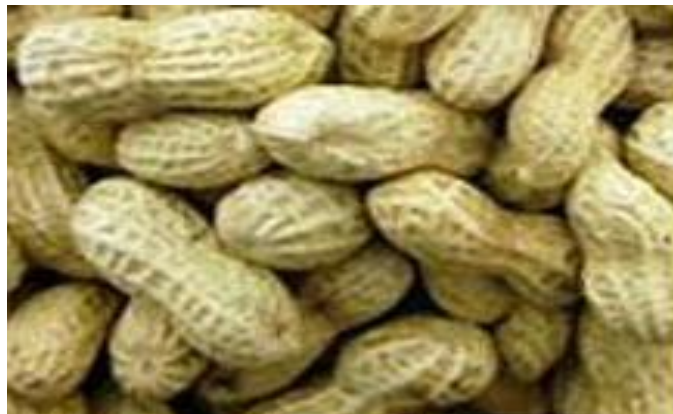

Plate 9: Left. Unshelled groundnuts

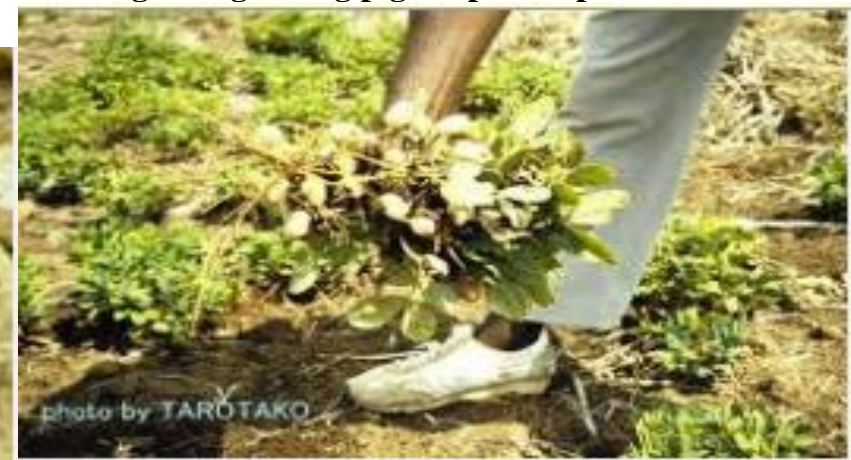

Right. Harvesting groundnuts from farm 


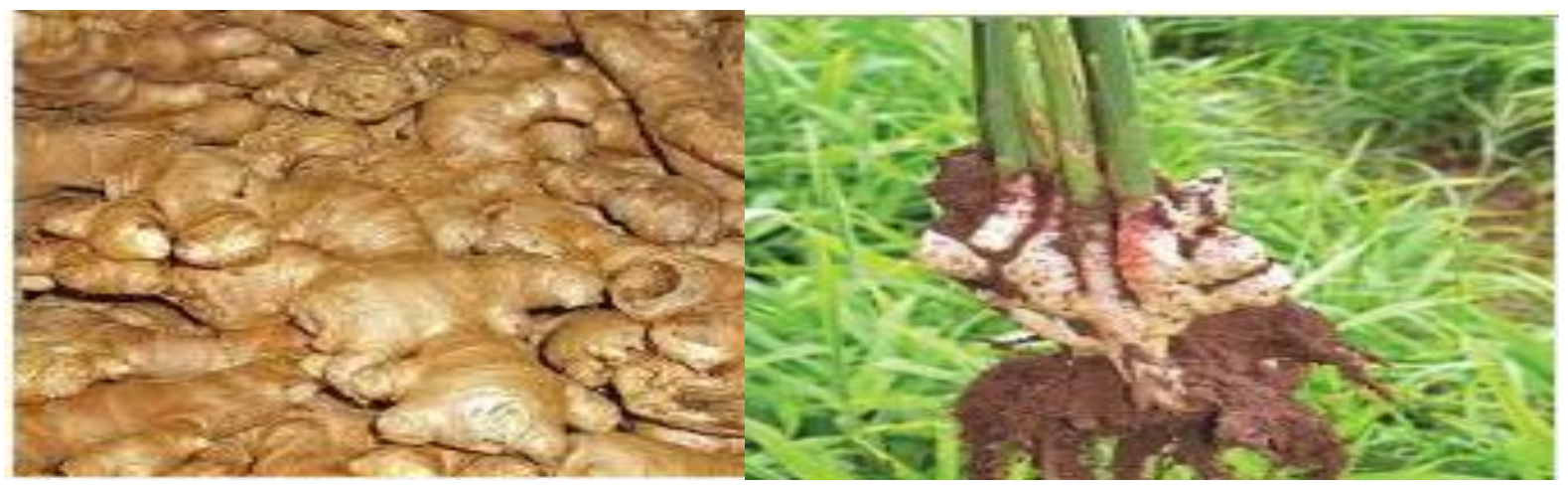

Plate 10: Left. Harvested ginger rhizomes

Right. A field of growing ginger crop

\section{References}

[1]. O. De Schutter, Building resilence: A human rights framework for world food and nutrition security, Report of the Special Rapporteur on the right to food to the UN General Assembly (A/HRC/9/23), 2008.

[2]. Action Aid, On the brink: Who's prepared for a climate and hunger crisis: http://www.actionaid.org/publications/brink-whos-bestprepared-climate-and-hunger-crisis, 2011, in Third World News (TWN) - TWN Agriculture Info: Ecological Agriculture Urgently Needed to Face Climate and Hunger Crisis, www.twnside.org.sg, www.biosafty-info.net, Accessed on $7^{\text {th }}$ December, 2011.

[3]. L. L. Ching, and D. Stabinsky, Ecological agriculture is climate resilient, Third World Network -TWN Durban Briefing Paper No. 1. 2011, www.twnside.org.sg; accessed on 29 November, 2011.

[4]. Chatham House, The feeding of the nine billion, London: Chatham House, 2009, in Action Aid Sustainable Smallholder Agriculture Key to Tackling Hunger. http://www.actionaid.org.uk/uk/doc_lib/sustainable_agriculture_aa.pdf, 2010.

[5]. NEP, The environmental food crisis, http://www.unep.org/publications/search/pub_details_s.asp?ID=4019, 2009, in Action Aid, Sustainable $\quad$ Smallholder $\quad$ Agriculture $\quad$ Key $\quad$ to $\quad$ Tackling Hunger, http://www.actionaid.org.uk/uk/doc lib/sustainable agriculture aa.pdf, 2010.

[6]. J. Vandermeer, G. Smith, I, Perfecto, and E. Quintero, Effects of industrial agriculture on global warming and the potential of smallscale agroecological techniques to reverse those effects, The New World Agriculture and Ecology Group, Ann Arbor, 2009, in L. L. Ching, and D. Stabinsky, Ecological agriculture is climate resilient, Third World Network -TWN Durban Briefing Paper No. 1, 2011, www.twnside.org.sg; accessed on 29 November, 2011.

[7]. Spore, Climate change, Spore special issue/ August, 2008. http://spore.cta.int

[8]. PROLINNOVA, Policy Brief: Strengthening local resilience to climate change, June 2011, http://www.prolinnova.net/sites/default/files/documents/thematic_pages/climate_change_pid/2011/prolinnova_policy_brief_climate _change_june_2011_lowres.pdf; accessed on $7^{\text {th }}$ December, 2011.

[9]. IAASTD, Agriculture at a crossroads, International Assessment of Agricultural Knowledge, Science and Technology for Development (Island Press, Washington DC: IAASTD, 2009), www.agassessment.org. in L. L. Ching, and D. Stabinsky, 2011, Ecological agriculture is climate resilient, Third World Network -TWN Durban Briefing Paper No. 1. www.twnside.org.sg; accessed on 29 November, 2011.

[10]. P. G. Jones, and P. K. Thornton, Croppers to livestock keepers: livelihood transitions to 2050 in Africa due to climate change, Environmental Science and Policy doi: 10. 1016/j.envsci., 2008.08.006.

[11]. TWNa, Third World News (TWN) Agriculture Info: Agro ecology Provides Technologies for Climate Change Adaptation, 2011, www.twnside.org.sg; www.biosafty-info.net, (accessed on $12^{\text {th }}$ December, 2011).

[12]. T. R. Omatseye, Speech by the Director General, NIMASA, at the 2009 World Maritime Day Celebrations, Abuja, Nigeria, in J. Iwori, GLOBAL WARMING: Poverty to Worsen in Nigeria, Others, THISDAY Newspaper, September 28, 2009, 31.

[13]. J. Roberts, Kenyan Professor Promotes Indigenous Crops to Solve Africa's Food Crisis, WORLDWATCH INSTITUTE, 2010, Worldswatch's Nourishing the planets blog; accessed on $18^{\text {th }}$ September, 2010.

[14]. C. E. Deive, Glosario de afronegrismos en la toponinia yel espanol hablado ensanto Domingo, Boletin del Museo del hombre Dominicano 5, Santo Domingo, Dominican Republic, 1974.

[15]. Fonio, Digitaria exilis: An African Cereal Crop, 2005, http//:Fonio.Cirad. Fr/en/plamte/cultivation.html.

[16]. W. O. Enwezor, E. J. Udo, N. J. Usoroh, K. A. Ayotade, J. A. Adepetu, V. O. Chude, C. I. Udegbe, Fertilizer use and Management: Practices for Crops in Nigeria, Series No. 2, FPDD/FMAWRRD, Lagos, Nigeria, 1989.

[17]. KADP, An Exploratory Survey of the Farming Systems of Southern Kaduna, Kaduna Agricultural Development Project (KADP)/ Institute for Agricultural Research (I.A.R.) Samaru, Zaria, Nigeria, 1987.

[18]. B. E. Sambo, J. C. Sah, U. U. Emeghara, and A. I. Sodimu, Acha (Digitaria Exilis) Production Practices, International Journal Of Food And Agricultural Research, 3 (2), 2006, 101-106.

[19]. H. C. Nzleibe, and C. C. Nwasike, The brewing potential of fonio (Digitaria exilis) malt compared to pearl millet (Pennisetum typhoids) malts and sorghum (Sorghum bicolor) malts, J. Inst. Brewing 101, 1995, 345-350.

[20]. S. M. Misari, E. H. Kwon-Ndung, S. N. Dachi, Fonio production in Nigeria, Poster presentation, Annual Research Review Meeting, Natural Cereal Research Institute, Badegi, Nigeria, 22-26 April, 1996.

[21]. N. D. Vietnameyer, N. E. BorLaugh, J. Axtell, G. W. Burton, J. R. Harlan, and K. O. Rachie, Fonio in Lost Crops of Africa. Vol.1, (Grains BOSTID Publications, National Academy Press, New York, 1996).

[22]. J. Carter, First step toward peace is eradicating hunger. International Herald Tribune, 17 June, 1999.

[23]. I. A. Jideani, Traditional and Possible Technological Uses of Digitaria exilis (acha) and Digitaria iburua (Iburu): An Overview, Plant Human Nutr.54, 1999, 363 - 374

[24]. A. Ibrahim, Hungary rice (Fonio): A neglected Cereal Crop, NAQAS News $\quad$ Letter 1 (4), 2001, 4-5.

[25]. B. E. Sambo, O. Akinyemi, O. R. Adejoba, G. G. Momodu, M. M. Olorukooba, and C. B. Danbaki, Boosting Acha (Digitaria Exilis) Production: Overcoming Its Constraints and Lack of Infrastructure Towards Alleviating Poverty, Youth Unemployment And 
Food Security For Sustainable Economic Development, Proceedings of the International Conference on the Global Food Crisis, Federal University of Technology (FUT) Owerri, Nigeria, April 19 - 24, 2009, $194-200$

[26]. J. R. Harlan, Genetic Resources in Africa, 65, in J. Janick and J.E. Simon (Eds.), New Crops. Wiley, New York, U.S.A, 1993.

[27]. J. P. Morales - Payan, J. R. Oritz, J. Cicero, F. Taveras, Digitaria exilis, as a Crop in the Dominican Republic, Supplementto: Trends in new Crops and new uses, in J. Janick and A Whipkey (Eds.), (ASHS Press, Alexandra, VA., 2002).

[28]. E. Sarr, and J. Prot, Penetration et Development des Juveniles d une Souche de Meloydogyne Javanica et d une Race B de M. Incognita Dans Les Raciness du Fonio (Digitaria exilis stapf.)-Revues Nematol. (8), 1985, 59 - 65

[29]. M. Khor, Food crisis, climate change and the importance of sustainable agriculture. Presentation at FAO food security summit, Rome, 4 June, 2008.

[30]. T. M. LaSalle, and P. Hepperly, Regenerative Organic Farming: A Solution to Global Warming, RODALE INSTITUTE, Pennsylvania, U. S. A., 2008.

[31]. L. L. Ching, The Case for Sustainable Agriculture: Meeting Productivity and Climate Challenges, Environmental \& Development Series 9 (Published by Third World Network (TWN), Penang, Malaysia, 2009).

[32]. TWNb, Third World News (TWN) Agriculture Info: Saving Native Seeds to Protect Food Heritage in Mexico, 2011, www.twnside.org.sg, www.biosafty-info.net, (accessed on $24^{\text {th }}$ December, 2011).

[33]. FAO, The $2^{\text {nd }}$ Report on the State of the World's plant genetic resources for food and agriculture, Commission on Genetic Resources for Food and Agriculture: Food and Agriculture Organization (FAO), Rome, 2010, 36

[34]. ETC Group, "Who Will Feed Us?" ETC Group, 2009, 1 - 10, in Third World News (TWN). Rio+20: What are the options when "Business as usual" is not an option? www.twnside.org.sg, accessed on 13 $3^{\text {th }}$ March, 2012.

[35]. TWNc, 2011. The executive summary of the Action Aid report, 2011, http://www. actionaid.org/publications/brink-whos-bestprepared-climate-and-hunger-crisis, in, Third World News (TWN) Agriculture Info: Ecological Agriculture Urgently Needed to face Climate and Hunger Crisis, www.twnside.org.sg; www.biosafty-info.net (accessed on $7^{\text {th }}$ December, 2011). 